\title{
Catholic Schools as Means of Promoting Peace and Justice in Nigeria
}

Anthony Bature*

\section{Abstract}

The paper examines the impact of the Nigerian education and the extent to which it contributes towards the promotion of peace and justice with specific reference to Catholic schools. The paper argues that the role of Catholic Church in providing education has immensely contributed to the growth and development of education in Nigeria. Due to the church's focused intervention, approximately 649 elementary schools, 384 secondary schools and 16 tertiary institutions have been established in Nigeria. Relying on documentary method of data collection and descriptive analytic approach, this study explains that Catholic schools have a significant role towards achieving a peaceful and equitable society in Nigeria. The article recommends more engaged efforts by other non-state institutions towards the building of developed educational institutions that will help in promoting peace and justice in Nigeria.

Keywords: Catholic Education, Catholic Schools, Peace, Justice.

\section{Introduction}

There seems to be no doubt that Catholic schools in Nigeria are abundant. Catholic schools, therefore, appear to have assumed

Department of Philosophy and Religious Studies, Federal University, Wukari, Taraba State, Nigeria; abature23@gmail.com 
pivotal position in the spiritual growth and intellectual life of the children in the country. Presently, there are 54 dioceses and vicariates in Nigeria. In 2012, the Catholic Secretariat of Nigeria documented that there are approximately 649 elementary schools, 384 secondary schools and 16 tertiary institutions in Nigeria. More specifically, the data also indicated that Nursery schools have 75 , 584 and Primary schools have 151,079 students while the number of students in secondary schools stands at 153, 388 and those in Tertiary institutions are at 19,960 . However, it is important to note that the data only reflects $65 \%$ of dioceses who submitted their information for inclusion in the list of schools to the Catholic Secretariat.

However, while there seems to be a general assumption that all children are being taught basic subjects and the concepts of both peace and justice, this premise needs detailed analysis. Arguably, the secularity of the Nigerian state sometimes remains a major challenge for the fulfillment or achievement of peace and justice. In fact, Nigeria is the land of many cultures and religions which seems to have led to several internal conflicts over the years. Perhaps, in this regard, understanding the dynamic nature and contradictions that have sustained this violence over the years is essential. Hence, there is the need to acquaint the younger generation with information to guide them for future decisions and assist them in their adoption of perspectives conducive for achieving peace. As Murphy explains:

Some cases of religious violence are so interwoven with cultural, political, and civilizational elements that they are, at their very roots, both religious and cultural. Each religious civilization constructs a sacred view of its own history, which describes its unique origins and its divine mission. These sacred narratives are often in conflict with competing religions and civilizations, and reinforce a sense of ethnocentrism and the seeds of civilizational misunderstanding and conflict. Some of the most intractable conflicts all over the world are the result of civilizational clashes between competing religious promises, sacred history, and divine truth. Violence 
is seen by many in these conflicts as a justifiable attempt to maintain the integrity of one's own identity from real or imagined enemies who seek to hinder the group from realizing its historical and divine mandate" (2011, p. 94).

Indeed, Mohammed stated that the factors that account for these conflicts are numerous. For him, these include ethnicity, religious differences and their manipulation, land, hunger, burgeoning population, chieftaincy and native/settlers syndrome. Recently, the Catholic Bishops Conference of Nigeria ( $\mathrm{CBCN})$ noted that Catholic education entails the integral formation of the human person with a view to offer optimal service to God and humanity. Interestingly, Catholic schools appear to have the distinction of guaranteeing healthy, cultural and educational pluralism that makes them accessible and preferable by all. As a result, many Catholic educational institutions tend to utilize the Catholic Policy on Education to consistently improve the quality of their educational services. This paper examines Nigerian education with specific focus on Catholic schools, with a view to determining the extent to which Catholic Schools assist in promoting peace and justice in Nigeria.

\section{Conceptualizing the Philosophy of Peace Education}

Peace education as a practice in schools is attributed to Maria Montessori, John Dewey and Paulo Freire, though earlier thoughts on education for peace are traced back to Erasmus and Socrates, among other scholars. Montessori worked to foster peace on three inter-related levels: the individual, community, and globe. The individual level relates to person-centered awareness of the self (i.e. body, mind, emotions, and spirit), whereas the community level refers to interpersonal relations (i.e. trust, openness, and interdependence), and the global level concerns cultural and environmental consciousness (Montessori, 1949). Dewey informed peace education through his work on the relationship between education and democracy, stating that one role of education is to foster active citizenship through the participation in processes of democracy (Dewey, 1916). Freire (1970) centered education on revealing systems of oppression, particularly through the 
exploration of language and identity and by challenging the banking-model of teaching and learning. All three educators sought to create education that was learner-centered and autonomous. This concept of classroom education represents social outcomes relevant to democratic political systems. Hence, autonomous learning relates to individual and national autonomy and democratic classroom participation models active citizenship in a democracy. Peace education is also found philosophically embedded in the work of authors like Tolstoy and Thoreau); social thinkers like Mead, Foucault, Adams; social learning scholars like Bandura and Walters; and activists like Gandhi, Martin Luther King, Syuu Kyi among others.

Peace education includes the cultivation of peace-building skills (e.g. dialogue, mediation, artistic endeavors). Peace educators, then, teach the values of respect, understanding, and nonviolence, present skills for analyzing international conflict, educate for alternative security systems, and use a pedagogy that is democratic and participatory. Thus, peace education as a practice and philosophy refers to matching complementary elements between education and society, where the social purposes (i.e. why teach), content (i.e. what to teach), and pedagogy (i.e. how to teach) of the educative process are conducive to fostering peace. Accordingly, peace education is a dialogical experience conducted through participatory learning, where learners communally and cooperatively grapple with contemporary issues (i.e. talking points) related to local and global contexts.

Plato in his philosophy gives very important place to the idea of justice. He used the Greek word "Dikaiosune" for justice, which comes very near to the work 'morality' or 'righteousness'; it properly includes within it the whole duty of man. It also covers the whole field of the individual's conduct in so far as it affects others. Plato contended that justice is the quality of soul, in virtue of which men set aside the irrational desire to taste every pleasure and to get a selfish satisfaction out of every object and accommodate themselves to the discharge of a single function for the general benefit.

Aristotle (1999) justifies the essence of justice in human society. This is to mean that peace is unattainable without justice as law is 
used to maintain such. For him, to be just is to keep the law; to be just is to be fair; to be just is to take only one's due. Hence, the character of a just person is that the person is law-abiding. Justice implies the observance of a mean or a middle point between extremes. By justice, he means moral disposition that makes human beings inclined to performing just acts. He does not only see justice as law, rather, he sees it as a moral disposition. Therefore, to be just implies two things, namely: to obey the law and to be morally inclined towards justice. He writes:

"For man, when perfected, is the best of animals, but, when separated from law and justice, he is the worst of all; since armed injustice is the more dangerous, and he is equipped at birth with the arms of intelligence and with moral qualities which he may use for the worst ends. Wherefore, if he have not virtue, he is the most unholy and the most savage of animals, and the most full of lust and gluttony. But justice is the bond of men in states, and the administration of justice, which is the determination of what is just, is the principle of order in political society" (2000, pp. 29-30).

The rule of justice is inclusive of everyone's common interest and does not cater to the interest of any singular person or community. Hence, justice refers to any idea/structure that produces and preserves the happiness of the society or political community. Aristotle understands justice to mean perfect virtue, which can be practised in two ways: in somebody's private life and in his relations to other people. The greatest expression of the capacity for justice is seen in the fact that a person is brought into relation to others, that is, the person becomes a member of, and participates in the community.

Augustine (saint) sees the importance of justice towards achieving peace in any human society, saying that a society, government and sovereignty devoid of justice is surely that of brigandry because such society cannot attain peace, which is the sole objective of people coming together to form a community. He writes that, 


\begin{abstract}
"In the absence of justice, what is sovereinty but organised brigandage? For, what are bands of brigands but petty kingdoms? They also are groups of men, under the rule of a leader, bound together by a common agreement, dividing their booty according to a settled principle" (1958, p. 56).
\end{abstract}

He discusses justice as a virtue and a task like Aristotle does, which is so essential in the running of human society. To him, "its task is to see that each is given what belongs to each. And this holds for the right order within man himself, so that it is just for the soul to be subordinate to God, and the body to the soul, and thus for the body and soul taken together to be subject to God" (Ibid, 432). This analysis of soul and body in relation to God by Augustine restates that harmony will continue to exist in a society if justice reigns there for reinstating a unity between soul and the body; and without justice, a society will lose its focus and everyone will continue to struggle for his/her own survival.

In Rawls' analysis, he examines the two principles of justice: liberty and wealth. On liberty, he opines that each person is to have an equal right to the most extensive total system of equal basic liberties compatible with a similar system of liberty for all; wealth, social and economic inequalities are to be arranged so that they are both to the greatest benefit of the least advantaged, consistent with the just savings principle and attached to offices and positions open to all under conditions of fair equality of opportunity. In this, Rawls asserts that if people had to choose principle of justice from behind "a veil of ignorance" - it is understood as a purely hypothetical situation characterised so as to lead to a certain conception of justice - that restricted what they could know of their own position in society, they would not seek to maximize utility. Rather, they would safeguard themselves against the worst possible outcomes (Rawls, 1972, pp. 136-137). Examining the issue of justice in the society, he opines that there are duties and obligations every participant owes the community. There is the need for individual to support just institutions (1972, p. 334). This is to state that there is the need for utmost symbiotic relationships among different and similar units in the society, which ought be 
based and established on the point of justice as without it, the society suffers a lot.

There seems to be several scholarly postulations on the meaning, relevance and importance of peace. Thus, peace as several other concepts appears not to have been given generally accepted definition. This can be attributed to global dynamics and changing socio-economic and cultural realities of the contemporary age (Odigbo, 2016, p. 12). These changes have also enhanced the understanding of peace as not necessarily the opposite of conflict or war. In fact, Odigbo maintained that the definitional vagueness that shredded the concept of peace has compelled scholars of the years to delve more into formulating more concepts for the purposes of clarifications. Indeed, peace was defined as the absence of war, partially because the early peace studies was strongly motivated by the reflections on the tragedies of the Second World War and by a sense of crisis of human survival caused by the danger of a total nuclear war between the two superpowers (Matsuo, 2005, p. 19).

The concept of peace terms, according to United Nations Declaration on Peace Culture or Culture of Peace and NonViolence, has been defined by the Programme of Action on a Culture of Peace adopted in 1999. The 1998 UN resolution on the culture of peace formulates this as "an integral approach to preventing violence and violent conflicts, and an alternative to the culture of war and violence based on education for peace, the promotion of sustainable economic and social development, respect for human rights, equality between women and men, democratic participation, tolerance, the free flow of information and disarmament."

In abstract terms, a culture of peace is a set of values, attitudes, traditions and modes of behaviour and ways of life based on: Respect for life, ending of violence and promotion and practice of non-violence through education, dialogue and cooperation; full respect for the principles of sovereignty, territorial integrity and political independence of States and non-intervention in matters which are essentially within the domestic jurisdiction of any State, in accordance with the Charter of the United Nations and international law; full respect for and promotion of all human 
rights and fundamental freedoms; commitment to peaceful settlement of conflicts; efforts to meet the developmental and environmental needs of present and future generations; respect for and promotion of the right to development; respect for and promotion of equal rights and opportunities for women and men; Respect for and promotion of the right of everyone to freedom of expression, opinion and information; adherence to the principles of freedom, justice, democracy, tolerance, solidarity, cooperation, pluralism, cultural diversity, dialogue and understanding at all levels of society and among nations and fostered by an enabling national and international environment conducive to peace (United Nations, Fifty-third session, 1999).

Galtung (1996, p. 183) explains that peace can be positive or negative. According to Galtung, negative peace could be seen as absence of war or direct physical violence whereas positive peace means the existence of conditions for political equality, social and economic justice among people. He, therefore, emphasizes the presence of sustainable institutional frameworks and mechanisms for distributive justice. That is, efforts towards enhancing capacity of individuals or groups to realise group or personal desires (1996, p. 184). Following from the above, peace can be seen as generally encompassing, which includes both the absence of conflict and the existence of socio-economic, political, religious as well as cultural equality among people of different or same geographical space. Thus, while education plays a crucial role to human development, peace and justice are entrenched in a society from the knowledge derived through education. According to Pius X1, education is defined as the sacred task of forming the character of the child and aiding him/her to attain the purpose of existence (Obemeata, 2012, p. 6). For him, it is stated in Canon Law it is important to note that "education must pay regard to the formation of the whole person so that all may attain their eternal destiny and at the same time promote the common good of society. He further stated that "children and young persons are therefore to be cared for in such a way that their physical, moral and intellectual talents may be develop in a harmonious manner so that they may attain a greater sense of responsibility and a right use of freedom and be formed to take an active part in social life" (Can., p. 795). 
Beales asserted that there were only two complete philosophies of education in the world worked out to the last detail (cited in Obemeata, 2012, p.3). According to Obemeata, one is the educational philosophy of Marxian Communism, which operated in the communist states and the other is the philosophy of education of the Catholic Church. He further explains that the Catholic Church believed that the ideations concerning education, concepts important for analysing education process and the ideal situations should generally constitute the Chruch's philosophy of education (Obemeata, 2012, p. 3). Following from the above, peace education can be seen as a process of acquiring, inculcating and developing values that enhances friendship, tolerance and harmonious co-existence among people and their environment. Peace education activities promote the knowledge, skills and attitudes that will help people either to prevent the occurrence of conflict, resolve conflicts peacefully, or create social conditions conducive to peace (see Insight on Conflict). According to Rasheed (1999, p. 9), peace education is the process of promoting the knowledge, skills, attitudes and values needed to bring about behaviour changes that will enable children, youth and adults to prevent conflict and violence, both overt and structural; to resolve conflict peacefully and to create the conditions conducive to peace, whether at an intrapersonal, interpersonal, intergroup, national or international level.

Harris (2004, p. 233) explains that peace education has both short and long term goals. For him, peace educators address the sources of immediate conflicts and give their students knowledge about strategies they can use to stop the violence. He further explained that in the long term, they hope to build in students' minds a commitment to non-violence and provide knowledge about nonviolent alternatives, so that when faced with conflicts they will choose the alternative that is peaceful. Within this context, peace education prepares the people for peace, creates a mentality that peace is the best option in every situation. Incidentally, the theory or philosophy of peace education has been assumed and not articulated. Galtung (1975, p. 334) noted that no theory for peace education existed and that there was clearly an urgent need for such a theory. However, the ultimate goal of peace education is predicated on the assumption that it has the capacity to prevent 
and resolve crisis and indeed increase the awareness for peace. It, therefore, ensures that people internalised efforts at achieving peace as virtue. Such virtues drive human behavior, attitude and morality. In fact, peace education does not only empower people to achieve peace; it also creates structures and builds bridges towards connecting societies and people for peaceful purposes.

\section{The Imperatives of Peace Education in Nigeria}

Peace education is very essential in every society. This is because it promotes and enhances quality education and social relations. Beyond this, it is necessary especially for multi-ethnic and developing societies that face myriads of challenges. Effective peace education mechanisms are needed to guide the society. In this view, conflict resolution, management and prevention help to build society where justice and peace flourish. Indeed, preserving the value system, norms and conventions becomes societal priority. These values are also been transferred from one generation to another through effective utilisation of peace education. Thus, Rasheed (1999, p.16) explained that the existing values and norms can either contribute to or hinder behaviour that promotes peace. For him, peace education promotes the development of values as the basis for behavioural change, and views behaviour as an indicator of an individual's or group's values. The effectiveness of peace education is increased when strategies are used that address the values of the entire community. He further stated that the process of changing behaviour proceeds through a sequence of stages for an individual. These stages include being aware of the issue (peace and conflict), being concerned about the issue, acquiring knowledge and skills pertaining to the issue, becoming motivated based on new attitudes and values, intending to take action, trying out a new behaviour (for example, peaceful conflict resolution, evaluating the trial and practicing the recommended behavior (Rasheed, 1999, p. 9).

Following from the above, it is important to state that these stages may vary but are very essential for the understanding of the challenges and adequate processes and mechanisms required for addressing them. Thus, since independence in 1960, Nigeria has been confronted with perennial instability and violence of different 
sorts. Integrating peace education in education curriculum plays significant role towards addressing these challenges. Also important are educational programmes that can enhance Nigerian value system, facilitate attitudinal change and promote human dignity. In fact, there is a need to revisit Nigeria's educational curriculum especially as the state faces new challenges of socioeconomic, political, religious as well security challenges. This will help to formulate new strategies in dealing with contemporary issues, understanding the dynamics of peace education to accommodate the emerging trend in achieving peace. It is within this context that the presence of social, economic and political justice, which are essential to the notion of peace and justice can be achieved in the Nigerian state.

The essence of peace cannot be achieved when rights of men/women are not upheld and on this basis is Pacem in Terris established; that is, for order and harmony in the world, rights of men and women must necessarily be respected. John XXIII explains that,

"But first we must speak of man's rights. Man has the right to live. He has the right to bodily integrity and to the means necessary for the proper development of life, particularly food, clothing, shelter, medical care, rest, and, finally, the necessary social services. In consequence, he has the right to be looked after in the event of ill health; disability stemming from his work; widowhood; old age; enforced unemployment; or whenever through no fault of his own he is deprived of the means of livelihood" (1963, no. 11).

He categorises these rights as follow: Rights Pertaining to Moral and Cultural Values; the Right to Worship God According to One's Conscience; the Right to Choose Freely One's State in Life; Economic Rights; the Right of Meeting and Association; the Right to Emigrate and Immigrate and Political Rights (nn., pp. 12 - 27). In the ensuing desire and respect for the rights of individuals, there are also duties that individuals must perform in the society for abundant peace, namely: Reciprocity of Rights and Duties Between Persons; mutual Collaboration; an Attitude of Responsibility; social 
Life in Truth, Justice and Charity and Freedom (nn., pp. 28 - 34). The whole essence of this form of education is that all and sundry in the society plays their roles in the quest for enduring peace in the society which must be the focus of any policy on education. This is examined and interpreted in the sense that an educational policy that respects the rights of others will set the best standard in all ramifications for such society.

In Gravissimum educationis - Declaration on Christian Education, Paul VI proclaims that,

“. . . attempts are being made everywhere to promote more education. The rights of men to an education, particularly the primary rights of children and parents, are being proclaimed and recognized in public documents. As the number of pupils rapidly increases, schools are multiplied and expanded far and wide and other educational institutions are established. New experiments are conducted in methods of education and teaching. Mighty attempts are being made to obtain education for all, even though vast numbers of children and young people are still deprived of even rudimentary training and so many others lack a suitable education in which truth and love are developed together" (1965, Introduction).

On the basis of education for the emancipation of the world and for removing man from enslavement, the church craves for the introduction of both moral and religious education in all schools by which recipients of education will be brought up in the struggle for peace and stability in the society as education is not about certification alone but such education must conform to the needs of the society. By this, Paul VI addresses that:

"The Church reminds parents of the duty that is theirs to arrange and even demand that their children be able to enjoy these aids and advance in their Christian formation to a degree that is abreast of their development in secular subjects. Therefore the Church esteems highly those civil authorities 
and societies which, bearing in mind the pluralism of contemporary society and respecting religious freedom, assist families so that the education of their children can be imparted in all schools according to the individual moral and religious principles of the families" (ibid., para no. 7).

In magisterium office, the church teaches that schools should be agents of peace. The church also provides platforms for dialogue that enhances cultural development as the gospel must be incarnated in the culture that it finds itself enmeshed in. In this quest, catholic schools are seen as sites of struggle for the human formation of the young minds in the spirit of freedom and charity in order to promote the goods of the earth and prepare the youth for the service of humanity. By this, the church reinforces and shares its belief that

"...the Catholic school can be such an aid to the fulfillment of the mission of the People of God and to the fostering of the dialogue between the Church and mankind, to the benefit of both, it retains even in our present circumstances the utmost importance. Consequently this sacred synod proclaims anew what has already been taught in several documents of the magisterium (para no. 26) namely: the right of the Church freely to establish and to conduct schools of every type and level. And the council calls to mind that the exercise of a right of this kind contributes in the highest degree to the protection of freedom of conscience, the rights of parents, as well as to the betterment of culture itself" (Ibid., para no. 8).

And since the establishment of Catholic Church in Nigeria, the Church has been progressively involved in several programmes and events aimed at contributing its quota to national development in Nigeria. As can be seen, Christianity in Nigeria dates back to the sixteenth $\left(16^{\text {th }}\right)$ century when the Portuguese introduced Latin Christianity in Benin and Warri (Adamolekun, 2008, p. 2). In his view, looking at Christianity from early beginning to the present time, many stages of development had taken place resulting in the 
planting and growth of churches. With liberalisation policy on education, many of the schools in various places in Nigeria, especially in Southern Nigeria, were either established or managed by the Church especially the Catholic missionaries. Evidently, as in other parts of the globe, it has always been a trend for Catholic mission to own or run schools. In fact, without the Church, Nigeria could have found it difficult to make the surprising progress it has recorded in education, especially beginning from 1960 when she got independence till now.

However, in spite of the above, the Church faces tremendous challenges in its effort to contribute to the educational development in Nigeria. Thus, the upsurge of the Catholic schools in the aftermath of government liberalisation policy tends to herald fear that the Catholic Church could use the schools to win converts to their disadvantage. This notion seems to hinder the growth of these schools at the initial stage. Indeed, the existence or prevailing liberty, freedom of worship among students and staff in the Catholic schools appears to have eliminated the seemingly scary threat of domination. This has encouraged people from other faiths and religions to become integral part of Catholic schools.

Secondly and perhaps more importantly, the management and funding of the established Catholic schools has remained a herculean task for the Church. The fact that government does not subsidise or provide subventions to the schools has increased the financial burden of the Church schools. Thus, this has led to high tuition fees in the schools thereby discouraging many who prefer their children to be trained in the mission schools. With the dearth of qualified teachers in the schools, the Church has to place salaries that will attract best teachers. Following from the above, it can be stated that while the Catholic Church has eminently contributed to educational development in Nigeria, the daunting challenges confronting education in Nigeria is yet to be eliminated.

It is imperative to assert that to promote education for peace and justice, the government and other non-governmental institutions should be committed towards ensuring that public ethics assist Nigerians to maintain a common cause. This will help in resolving conflict that threatens peace and unity of the Nigerian state. In fact, there is need to improve mechanisms of dialogue among ethnic and 
religious leaders and their adherents in a manner that will mitigate suspicions and differences inherent in a multi-cultural and religious society. In doing this, the role of the Church is crucial. Thus, in the support of dialogue as an essential approach to fostering peace and justice in a multi-cultural and religious society, Sherwin and Kasimow (1999, pp. 9-10), quoting John Paul II, maintain that:

\begin{abstract}
"Dialogue, in a sense, is even more urgent with exclusivists and exclusivists than with pluralists. The Pope has stated many times in different contexts that dialogue not only leads to understanding the other, but is a path that deepens our own selfunderstanding ... Since Vatican II Council, the Catholic has been fully committed to pursuing the path of dialogue and cooperating with members of other religions. Interreligious dialogue is a precious means by which the followers of various religions discover shared points of contact in the spiritual life, while acknowledging the differences which exist among them. The Church respects the freedom of individuals to seek the truth and to embrace it according to the dictates of conscience. In this light she firmly rejects proselytism and the use of unethical means to gain conversions".
\end{abstract}

Indeed, there is need to establish an agency which will serve as intervention mechanism towards managing conflict situation through dialogue. Beyond this, a peace curriculum should be developed at the federal level for schools and universities in Nigeria. No country attains sustainable development and progress without the liberty of peace. In the wake of the continuous ethnoreligious crisis in Nigeria, the government, through ministry of education, should stress the importance of values of respect and peace in school curricula. Peace education curricula should take priority and be implemented as an integral part of the national educational reform in all Nigerian institutions, from primary school to the university level. 


\section{Conclusion}

From the analysis, this study examined Nigerian education with specific reference on how Catholic schools contribute its quota to national development. It explained that the increasing number of Catholic diocese and vicariates has increased the number of Catholic schools in Nigeria. The paper explains that the role of Catholic Church in providing education has immensely contributed to the growth and development of education in Nigeria. The Church extended its boundaries and established approximately 649 elementary schools, 384 secondary schools and 16 tertiary institutions in Nigeria. Indeed, the Catholic schools have over the years been in the vanguard of providing education that enhances tolerance, cooperation and the realization of individual potentials for the good of the society.

\section{References}

Aristotle. (1999). Nicomachean Ethics. (Terence Irwin Trans., 2nd ed.). Indianapolic:Hackett.

Aristotle. (2000). Politics. translated by Benjamin Jowett. New York: Dover Publications Inc.

Augustine (saint). City of God, edited by Vernon Bourke. New York: An Image Book.

Galtung, J. (1975). Three Approaches to Peace: Peacekeeping, Peacemaking and Peacebuilding. In J. Galtung (Ed.), Peace, War and Defence: Essays in Peace Research. Copenhagen: Christian Ejlers.

John XXIII. (1963). Pacem in Terris - Peace on Earth. An Encyclical Letter, April 11.

Harris, I. (2004). Peace Education: Definition, Approaches and Future Directions. Peace Literature and Art 1 (2), 14-29.

Mohammed, S. A. (2004). The Impact of Conflict on the Economy: The case of Plateau State of Nigeria. Paper presented at the Overseas Development Institute, ODI, Nigerian Economic Summit Group Workshop: London, England.

Murphy, R. A. (2011). The Blackwell Companion to Religion and Violence. Oxford: Blackwell Publishing Ltd. 
Obemeata, J. (2012). The Catholic Church Policy and Education in Nigeria and National Policy on Education. Retrieved from http:/ / www.obemeata.com.

Odigbo, J. (2016). Identity Crisis and Post-Conflict Peace Building in Wukari, 1999-2015. A Ph.D seminar Presented at the Department of Political Science, University of Nigeria Nsukka, April 6.

Paul VI (1965), Gravissimum Educationis - Declaration on Christian Education. Vatican II Document, October 28.

Peace Direct. Insight on Conflict. Retrieved from https://www.insightonconflict.org/themes/peace-education/) Rasheed, S. (1999). Peace Education in UNICEF. Working Paper, UNICEF Programme Division: New York.

Rawls, J. (1972). A Theory of Justice. London: Oxford University Press.

Sherwin, B., \& Kasimow, H. (1999). John Paul II and Interreligious Dialogue. Eugene: Orbis Books. 